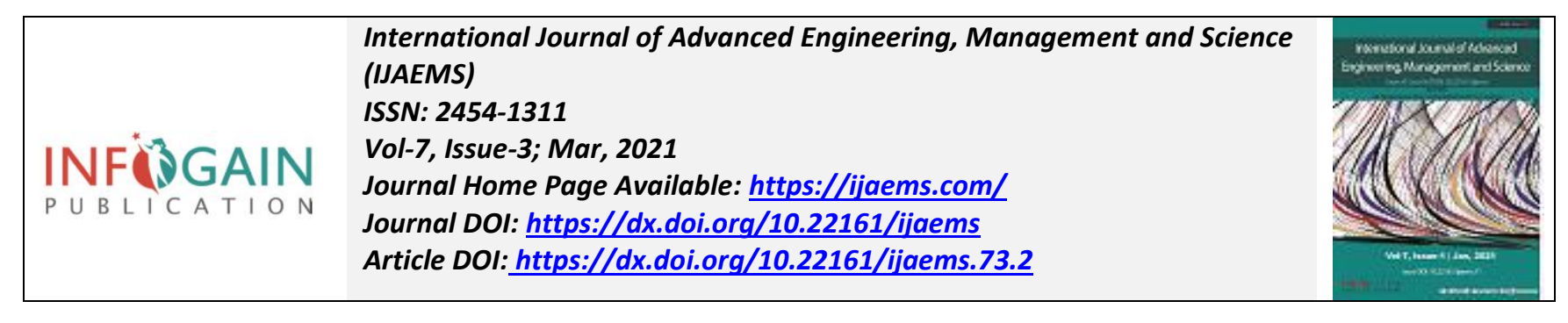

\title{
Preferred Essential Entrepreneurial Skills of Employees in the Hospitality Industry
}

\author{
Anna Margarita T. de Leon, Hannah Kaziel A. Gaya, Crispin B. Catle, Alan Joyce DD. \\ Oracion, Lizelle C. Rodriguez
}

Received: 14 Dec 2020; Received in revised form: 11 Feb 2021; Accepted: 27 Feb 2021; Available online: 10 Mar 2021 (C)2021 The Author(s). Published by Infogain Publication. This is an open access article under the CC BY license (https://creativecommons.org/licenses/by/4.0/).

\begin{abstract}
This research study aimed to establish and discover the various entrepreneurial skills of an employee preferred in the hospitality industry. Through this evaluation, the researchers would become more aware of the necessary traits an employee should possess, hence preferred by employers. Entrepreneurial skills as used in this study were associated with the variables: personal characteristics, interpersonal skills, critical and creative thinking skills, and practical skills. The researchers used the descriptive method of research through a survey questionnaire administered to the heads in the hospitality industry. Based on the findings, the preferred entrepreneurial skills desired in an employee were being hospitable, ethical, knowledgeable, and pro-activeness in work.

Keywords - Ethical, entrepreneurial skills, hospitable, hospitality industry, preferred employee traits.
\end{abstract}

\section{INTRODUCTION}

Business is a major contributor to the world economy. It is the most important in capitalist economies. All business entities are formed to earn a profit that will increase the asset of its owners and the business itself. As the basic needs and wants of the people increases, the number of people who are eager to gain profit also increases thus leads to the existence of the business. At present, a lot of business ventures can be found in the country and one of the most common forms of this profitoriented activity is the management of hotels and restaurants, which satisfies the needs of guests and diners.

As the hospitality and tourism industry moves into the next century, its future success depends on whether each country can upgrade the level of training for those already engaged in this field, and design new training approaches for those entering this employment sector. Education has become more highly valued. Therefore, hospitality and tourism programs throughout the world are racing to keep pace with the demands of a rapidly changing and highly dynamic industry.

Entrepreneurial skills encompass skills that target personal, interpersonal, creative, and practical aspects. It seeks out change, it embraces development and innovation and continuously pursues improvement and opportunities. Entrepreneurial activities are immensely significant for economic growth and national development in both formal and informal sectors (Al-Mamun et al., 2016). Having the right set of skills and characteristics can greatly contribute to the efficiency and effectiveness of an organization or enterprise. Personal characteristics, interpersonal skills, critical and creative thinking skills, and practical skills all have their own bearing on individual success. An individual's capabilities can boost one's personal strength in efficiently managing an enterprise (Man et al., 2002). Gerli et al. (2011) emphasized that it is important for entrepreneurs to hone certain competencies to enable firm performance. This is also particularly true for employees as they are the greatest asset of an organization. Mitchelmore and Rowley claimed that entrepreneurial competencies can advance enterprise performance, growth, and economic development.

Good management is a result of a smooth operation. The flow of management starts with the people who have the skills and capabilities of running the operations. People associate requiring entrepreneurial skills with those who only intend to set up their own 
business. However, employers nowadays look for an entrepreneurial mindset in their employees. The European Council (2006) labeled entrepreneurship as one of the eight key competencies that all individuals should have in order to facilitate business creation and innovation (Landström et al., 2012) and to have a successful professional life (Daniel et al., 2017); the entrepreneur is seen not only as a person who is capable of assuming risks and starting a business but also as an individual who uses his/her skills and characteristics in order to create value in a company (Gundry, Ofstein \& Kickul, 2014).

The researchers chose to explore this kind of study to determine the entrepreneurial skills of an employee most desired in the hospitality industry. This research study sought to describe the entrepreneurial skills of employees preferred (Subia, Mones \& Alfonso, 2017) in the hospitality industry, and recommend a plan for human resource management and development.

\section{METHODOLOGY}

The study used the descriptive research design. The process of descriptive research goes beyond mere gathering and tabulation of data. It involves the understanding of the meaning or significance of what is described. Thus, the description is often a combination with comparison- and-contrast that comprise organizations, classifications, measurements, interpretation, and evaluation.

This study consisted of 6 hotels with 6 immediate supervisors as respondents situated within the city using purposive sampling in data gathering. A 5-point Likert scale was used in the responses of the informants to allow their level of preference; agreement or disagreement on the matter being described where 5 has an equivalent verbal analogy of Highly Preferred to be the highest and 1 as the lowest denoted by Least Preferred, hence

Table 1. The point, Range and Verbal Analogy on the Preference of the Respondents

\begin{tabular}{|c|c|c|}
\hline Point & Range & $\begin{array}{c}\text { Verbal } \\
\text { Analogy }\end{array}$ \\
\hline 5 & $4.21-5.00$ & $\begin{array}{c}\text { Highly } \\
\text { Preferred }\end{array}$ \\
\hline 4 & $3.41-4.20$ & Preferred \\
\hline 3 & $2.61-3.40$ & $\begin{array}{c}\text { Moderately } \\
\text { Preferred }\end{array}$ \\
\hline 2 & $1.81-2.60$ & Less Preferred \\
\hline 1 & $1.00-1.80$ & Least Preferred \\
\hline
\end{tabular}

\section{RESULTS AND DISCUSSION}

Entrepreneurial skills of an employee preferred in the hospitality industry as rated by their immediate supervisor. This was rated from the numerical value of 5 as being Highly Preferred to 1 being Not Preferred.

The succeeding tables would show the entrepreneurial skills considered in this study labeled as Table 2. Personal Characteristics, Table 3. Interpersonal Skills, Table 4. Critical and Creative Thinking Skills, and Table 5. Practical Skills.

Shown in Table 2 are the results of the survey in the Item Personal Characteristics. This trait as a whole makes up one's personality so that employers will try to be assertive to look for these qualities in an employee; hence

Table 2. Personal Characteristics

\begin{tabular}{|c|c|c|c|}
\hline $\begin{array}{c}\text { Personal } \\
\text { characteristics }\end{array}$ & $\begin{array}{c}\text { Weighted } \\
\text { Mean }\end{array}$ & $\begin{array}{c}\text { Verbal } \\
\text { Description }\end{array}$ & Rank \\
\hline Optimism & 4.13 & Preferred & 7 \\
\hline Initiative & 4.43 & Highly Preferred & 5.5 \\
\hline Resilience & 4.43 & Highly Preferred & 5.5 \\
\hline Adaptability & 4.47 & Highly Preferred & 4 \\
\hline Cooperation & 4.63 & Highly Preferred & 2 \\
\hline Efficiency & 4.53 & Highly Preferred & 3 \\
\hline Hospitable & 4.80 & Highly Preferred & 1 \\
\hline $\begin{array}{c}\text { Overall } \\
\text { Weighted } \\
\text { Mean }\end{array}$ & 4.49 & Highly Preferred & \\
\hline
\end{tabular}

It can be noted that being hospitable the highest weighted mean of 4.80 . It is followed by cooperation with a weighted mean of 4.63 , then by the efficiency with a weighted mean of 4.53 , adaptability with the weighted mean of 4.47 , initiative and resilience with both having a weighted mean of 4.43 , and lastly by optimism with a weighted average of 4.13 . While the respondents agree that their employees should possess all these characteristics, being hospitable is of significant importance to them as this should be portrayed by most, if not all, hospitality industry members. Being hospitable to others, and particularly outsiders requires both certain skills and certain mindsets. Without the proper mindsets, one will be unable to give off the friendly vibe that hospitality requires. And without the right skills, one will also struggle to provide the proper help. It takes some practice to develop, but being hospitable to other people is a valuable character trait.

Table 3 tackled interpersonal skills as a necessary trait in the hospitality industry as it helps to develop 
relationships with people. It is also known as social skills or an individual's capacity or tolerance in interacting with others.

Table 3. Interpersonal Skills

\begin{tabular}{|c|c|c|c|}
\hline $\begin{array}{l}\text { Interpersonal } \\
\text { Skills }\end{array}$ & $\begin{array}{c}\text { Weighted } \\
\text { Mean }\end{array}$ & $\begin{array}{c}\text { Verbal } \\
\text { Description }\end{array}$ & Rank \\
\hline Leadership & 4.43 & $\begin{array}{c}\text { Highly } \\
\text { Preferred }\end{array}$ & 6 \\
\hline Motivation & 4.47 & $\begin{array}{c}\text { Highly } \\
\text { Preferred }\end{array}$ & 2.5 \\
\hline $\begin{array}{c}\text { Communication } \\
\text { Skills }\end{array}$ & 4.37 & $\begin{array}{c}\text { Highly } \\
\text { Preferred }\end{array}$ & 4.5 \\
\hline $\begin{array}{c}\text { Listening } \\
\text { Capabilities }\end{array}$ & 4.37 & $\begin{array}{c}\text { Highly } \\
\text { Preferred }\end{array}$ & 4.5 \\
\hline $\begin{array}{l}\text { Personal } \\
\text { Relations }\end{array}$ & 4.47 & $\begin{array}{c}\text { Highly } \\
\text { Preferred }\end{array}$ & 2.5 \\
\hline Negotiation & 4.33 & $\begin{array}{c}\text { Highly } \\
\text { Preferred }\end{array}$ & 7 \\
\hline Ethics & 4.63 & $\begin{array}{l}\text { Highly } \\
\text { Preferred }\end{array}$ & 1 \\
\hline $\begin{array}{c}\text { Overall } \\
\text { Weighted Mean }\end{array}$ & 4.44 & $\begin{array}{l}\text { Highly } \\
\text { Preferred }\end{array}$ & \\
\hline
\end{tabular}

The data suggest that ethics has the highest weighted mean of 4.63 followed by personal relations and motivation where both got a weighted mean of 4.47 , then by leadership (Ramos, et al, 2019) with a weighted mean of 4.43, and by communication skills and listening capabilities with a weighted mean of 4.37 , and lastly by negotiation with a weighted mean of 4.33. The respondents believe that when their employees possess the traits of being highly ethical, the rest of the cited characteristics will follow. If their employees possess the right moral values, they will most likely be effective and efficient in whatever undertaking they make. Establishing a healthy organizational environment is by fostering ethical awareness, practices, and behavior enhances employee satisfaction, reduces employee turnover intentions, improves visitor experience, and increases the organization's profit (Cheng et al., 2013).

Table 4 covers the area of an employee's critical and creative thinking skills as they evaluate knowledge in the workplace, interpret ideas, seek possibilities, consider alternatives, being resourceful, and solve problems in a logical manner.
Table 4. Critical and Creative Thinking Skills

\begin{tabular}{|c|c|c|c|}
\hline $\begin{array}{c}\text { Critical and } \\
\text { Creative } \\
\text { Thinking Skills }\end{array}$ & $\begin{array}{l}\text { Weighted } \\
\text { Mean }\end{array}$ & $\begin{array}{c}\text { Verbal } \\
\text { Description }\end{array}$ & Rank \\
\hline Goal Setting & 4.47 & $\begin{array}{c}\text { Highly } \\
\text { Preferred }\end{array}$ & 2 \\
\hline Planning & 4.43 & $\begin{array}{c}\text { Highly } \\
\text { Preferred }\end{array}$ & 3 \\
\hline Organizing & 4.30 & $\begin{array}{c}\text { Highly } \\
\text { Preferred }\end{array}$ & 4 \\
\hline $\begin{array}{l}\text { Decision } \\
\text { Making }\end{array}$ & 4.20 & Preferred & 5 \\
\hline Knowledge & 4.63 & $\begin{array}{c}\text { Highly } \\
\text { Preferred }\end{array}$ & 1 \\
\hline $\begin{array}{c}\text { Overall } \\
\text { Weighted Mean }\end{array}$ & 4.41 & $\begin{array}{c}\text { Highly } \\
\text { Preferred }\end{array}$ & \\
\hline
\end{tabular}

Critical thinking involves logical thinking (Subia, 2020; Subia, et al, 2020) and reasoning. It encompasses generating something new to the point of being innovative. This is what the respondents need in their employees. The highest weighted mean falls under the Item knowledge with 4.63 , followed by goal setting with a weighted average of 4.47 , then by planning with a weighted average of 4.43, and organizing with a weighted mean of 4.30, respectively, and lastly in decision making with a weighted average of 4.20. 'Knowledge is power' may sound like an over-used cliché, but it really is true when it comes to staying relevant in the extremely competitive hospitality industry. The respondents agree that when their employees are knowledgeable, they will be able to do anything to succeed and excel in their work. They further opined that an employee should have the ability and knowledge in order to have skill.

Table 5 is the fourth domain considered in this study that includes the employee's ability to analyze and creatively solve practical problems while integrating skills learned from previous experiences, which can also be a window to excel while advancing career opportunities.

Table 5. Practical Skills

\begin{tabular}{|c|c|c|c|}
\hline Practical Skills & $\begin{array}{c}\text { Weighted } \\
\text { Mean }\end{array}$ & $\begin{array}{c}\text { Verbal } \\
\text { Description }\end{array}$ & Rank \\
\hline Knowledgeable & 4.47 & $\begin{array}{c}\text { Highly } \\
\text { Preferred }\end{array}$ & 2 \\
\hline Manual dexterity & 4.00 & Preferred & 5 \\
\hline $\begin{array}{c}\text { Flexibility and } \\
\text { modularity }\end{array}$ & 4.40 & $\begin{array}{c}\text { Highly } \\
\text { Preferred }\end{array}$ & 3 \\
\hline Mobility & 4.30 & Highly & 4 \\
\hline
\end{tabular}




\begin{tabular}{|c|c|c|c|}
\hline & & Preferred & \\
\hline Proactiveness & 4.60 & $\begin{array}{c}\text { Highly } \\
\text { Preferred }\end{array}$ & 1 \\
\hline $\begin{array}{c}\text { Overall Weighted } \\
\text { Mean }\end{array}$ & 4.35 & $\begin{array}{c}\text { Highly } \\
\text { Preferred }\end{array}$ & \\
\hline
\end{tabular}

It can be noted that being proactive has the highest weighted mean of 4.60 followed by knowledgeable with a weighted mean of 4.47 , then by flexibility and modularity with a weighted mean of 4.40 , and mobility with a weighted mean of 4.30 , and lastly by manual dexterity with a weighted mean of 4.00 . Being proactive is somewhat different than being prepared. The respondents know that being prepared in any task or endeavor is important, it is knowing what to do when the customers or the guests need something. Being proactive is knowing the needs of the customers or guests before they even have to ask, and this is what the respondents want to instill in their employees. This is a desirable trait because this is overcoming any obstacles while being in control of the situation.

Proactivity is not only conducive to the personal development of employees such as improving employee performance, promoting career success, obtaining clear role positioning, better job satisfaction, and enhancing employee creativity (Parker \& Collins, 2010; Saks, Gruman, \& Cooper-Thomas, 2011; Kim, Hon, \& Crant, 2009; Kim, Hon, \& Lee, 2010) and also key factors that determine the success of an organization and its competitive advantage (Crant, 2000; Grif-fin, Neal, \& Parker, 2007, Frese, Kring, Soose, \& Zempel, 1996; Parker, 2000).

\section{CONCLUSION AND RECOMMENDATIONS}

This study was conducted to explore the various entrepreneurial skills in an employee preferred in the hospitality industry. This consisted of personal characteristics, interpersonal skills, critical and creative thinking skills, and practical skills.

Based on the researchers' findings, the following conclusions were drawn:

1. Most of the respondents were in their productive age and experienced in the field of hospitality management, female, college graduates, and holding supervisory positions.

2. In terms of personal characteristics, it can be noted that being hospitable is the highest.

3. As to interpersonal skills, it can be seen that ethics is the highest.

4. As to critical and creative thinking skills, the highest belongs to the variable knowledge.
5. As to practical skills, it can be noted that being proactive is the highest.

Based on the findings and conclusion, the following are recommended:

1. Since an employee's entrepreneurial skills can be honed over time, interaction with people can improve a person's values and attitudes.

2. More personality development subjects should be offered in the school's curriculum.

3. The organization's Human Resource Office can initiate a plan for employee development for their personal and professional growth.

4. An organization may institutionalize a system in developing employee competencies, recruitment, performance management, and rewards and recognition.

\section{REFERENCES}

[1] Abas, M. and Imam, O. (2016) Graduates' Competence on Employability Skills and Job Performance. International Journal of Evaluation and Research in Education (IJERE). Vol.5, No.2, June 2016, pp. 119 125 https://files.eric.ed.gov/fulltext/EJ1108534.pdf

[2] Barazandeh, M. et al. (2015) Investigating the effect of entrepreneurial competencies on business performance among early-stage entrepreneurs Global Entrepreneurship Monitor (GEM 2010 survey data). Journal of Global Entrepreneurship Research. Published Aug. 19, 2015 https://journal-

jger.springeropen.com/articles/10.1186/s40497-015-0037-4

[3] Burrus, J. (2017) Using O*NE Using O*NET to Develop a Framework of Job Characteristics to Potentially Improve the Predictive Validity of Personality Measures. Personnel Assessment and Decisions. Vol3, Issue 1.

https://scholarworks.bgsu.edu/cgi/viewcontent.cgi?article= 1026\&context $=$ pad

[4] Chatterjee, N. and Das, N. (2016) A Study on the Impact of Key Entrepreneurial Skills on Business Success of Indian Micro-entrepreneurs: A Case of Jharkhand Region. SAGE Journals, Published Feb. 14, 2016, https://doi.org/10.1177/0972150915610729

[5] Coffelt, T. et al. (2019) Employers' Perspectives on Workplace Communication Skills: The Meaning of Communication Skills. SAGE Journals. https://doi.org/10.1177/2329490619851119

https://journals.sagepub.com/doi/abs/10.1177/23294906198 $\underline{51119}$

[6] Dench, S. (1998) Employer's Perceptions Key Skills. The Institute of Employment Studies. University of Sussex, BN. https://www.employmentstudies.co.uk/system/files/resources/files/349.pdf

[7] Fayolle, A. et al. (2014) Beyond entrepreneurial intentions: values and motivations in entrepreneurship. International Entrepreneurship and Management Journal, March 2, 2014 
https://link.springer.com/article/10.1007/s11365-014-03067

[8] Kirkley, W. (2016) Entrepreneurial behavior: the role of values. International Journal of Entrepreneurial Behavior and Research. DOI: 10.1108/IJEBR-02-2015-0042

https://www.researchgate.net/publication/301535374_Entre preneurial behaviour the role of values

[9] Krieger, A. et al. (2018) Skill variety in entrepreneurship: A literature review and research directions. International Review of Entrepreneurship, 16(1), 29-62.

https://www.researchgate.net/publication/326742484_Skill _variety_in_entrepreneurship_A_literature_review_and_res earch directions

[10] Markos, S. (2010) Employee Engagement: The Key to Improving Performance.International Journal of Business and Management. Vol. 5, No. 12, December 2010

http://citeseerx.ist.psu.edu/viewdoc/download?doi=10.1.1.4 66.1591\&rep=rep1\&type $=$ pdf

[11] Meeks, G. (2017) Critical Soft Skills to Achieve Success in the Workplace. Walden Dissertations and Doctoral Studies. Walden University.

https://scholarworks.waldenu.edu/cgi/viewcontent.cgi?artic $\underline{\mathrm{le}=5180 \& \text { context }=\text { dissertations }}$

[12] Ramos,J., Salangsang,S., Nacpil,L., Subia, G. and Cruz, J.(2019). Leadership Styles of Industrial Engineers in Pottery Industries in Pampanga. International Journal of Advanced Engineering, Management and Science (IJAEMS) [Vol-5, Issue-6, Jun 2019]https://dx.doi.org/10.22161/ijaems.5.6.10 ISSN: 2454-1311

[13] Sackett, P. and Walmsley, P. (2014) Which Personality Attributes Are Most Important in the Workplace? Sage Journals https://doi.org/10.1177/1745691614543972 https://journals.sagepub.com/doi/abs/10.1177/17456916145 43972

[14] Subia, G. S. Treasure Chess: Worthy Contributions of the Game in the Lives of Student Champions. The Normal Lights, (2020), 14(1),100-121.

[15] Subia, G., Marcos, M., Valdez, A., Pascual, L. \& Liangco, M. (2020). Cognitive Levels as Measure of Higher Order Thinking Skills in Senior High School Mathematics of Science, Technology, Engineering, and Mathematics (STEM)Graduates. Technology Reports of Kansai University. Volume 62, Issue 3, pp 261-268.

[16] Subia, G.,Mones, E. and Alfonso, A.(2017). Existing and Preferred Organizational Culture at Wesleyan University Philippines. International Journal of Management and Commerce Innovations. ISSN 2348- 7585, Vol.5, Issue 2, pp: (796-801).

[17] Truitt, D. (2011) The Effect of Training and Development on Employee Attitude as it Relates to Training and Work Proficiency. SAGE Journals. https://doi.org/10.1177/2158244011433338 https://journals.sagepub.com/doi/10.1177/21582440114333 $\underline{38}$

[18] Vamvaka, V. et al. (2020) Attitude toward entrepreneurship, perceived behavioral control, and entrepreneurial intention: dimensionality, structural relationships, and gender differences. Journal of Innovation and Entrepreneurship https://innovationentrepreneurship.springeropen.com/articles/10.1186/s1373 1-020-0112-0 